\title{
PERFORMANCE "ELLEN WITH WILL SMITH FULL INTERVIEW” TALK SHOW: EMOTIVE LANGUAGE FUNCTIONS
}

\author{
Kartika $^{1}$, Faidah Yusuf ${ }^{2}$, Umar Thamrin ${ }^{3}$ \\ Mahasiswa UIN Makassar ${ }^{1}$, Dosen UIN Makassar ${ }^{2}$, Dosen UIN Makassar ${ }^{3}$ \\ Jln. H.M. Yasin Limpo, Samata. Gowa. South Sulawesi \\ Kartikatika241@gmail.com¹ ${ }^{1}$ faidah.yusuf@uin-alauddin.ac.id², \\ umar2x.umar@gmail.com ${ }^{3}$
}

\begin{abstract}
This study focused to analyze the emotive language functions in the Ellen DeGeneres talk show. The objective of this study was to describe the emotive language functions work in the conversation performance by the actors "Ellen with Will Smith Full Interview" talk show. This study used qualitative method. The data were analyzed based on Jacobson's theory. The result of this study showed that only 5 of 17 emotive language functions were applied. The emotive language functions applied were pleasure, like, dislike, surprise, gratitude. While the emotive language functions that not applied were hope, satisfaction, dissatisfaction, worry, preference, sympathy, intentions, want, desire, dear and disappointment. This study found that the most emotive function that frequently used in the Ellen DeGeneres Talk Show was "like expression". The emotive function in the Ellen DeGeneres talk show worked to express the actor's feelings to other people based on the context and situation of the conversation.
\end{abstract}

Keywords: Performance, Talk Show, Emotive Language Functions

\begin{abstract}
Abstrak: Studi ini difokuskan untuk menganalisis fungsi bahasa emotif dalam talk show Ellen DeGeneres. Tujuan dari penelitian ini adalah untuk mendeskripsikan fungsi bahasa emotifik yang bekerja dalam penampilan percakapan oleh aktor "Ellen with Will Smith Full Interview". Penelitian ini menggunakan metode kualitatif. Data dianalisis berdasarkan teori Jacobson. Hasil penelitian ini menunjukkan bahwa hanya 5 dari 17 fungsi bahasa emotif yang diterapkan. Fungsi bahasa emotif yang diterapkan adalah kesenangan, suka, tidak suka, terkejut, syukur. Sedangkan fungsi bahasa emotif yang tidak diterapkan adalah harapan, kepuasan, ketidakpuasan, kekhawatiran, preferensi, simpati, niat, keinginan, keinginan, sayang dan kekecewaan. Studi ini menemukan bahwa fungsi paling emotif yang sering digunakan dalam Ellen DeGeneres Talk Show adalah "like expression". Fungsi emotif dalam talk show Ellen DeGeneres berfungsi untuk mengekspresikan perasaan aktor kepada orang lain berdasarkan konteks dan situasi percakapan.
\end{abstract}

Kata kunci: Pertunjukan, Talk Show, Fungsi Bahasa Emotif

\section{INTRODUCTION}

The gesture is a form of non-verbal communication, where the actions of the body are seen to communicate certain messages. When the speakers deliver the message, then shown with the gesture, so the listeners will more easily understand what the speakers mean. Therefore, the listeners must look at the context of the conversation. The message received by the listener is influenced by the situation that occurs during the conversation. By looking at the conversation context, the listeners 
can interpret the meaning of the conversation, it is called contextual meaning. When gesture occurs, then the listeners see the context, so the meaning occurs from the interpretation of the listeners, it is called the emotive function. Based on Jacobson (1960) in Chaer, the emotive function is a function where the speakers express their attitude towards what they are speaking about. That is the speakers not only express their emotions through language, but also show those emotions with a gesture when speaking out.

The emotive function relate to the characters of the conversations. Characters cannot show their emotion only though expressions, but they have to be contextual or in a single way. In the research which was conducted by (Wahyuni, 2014) in her thesis, she found that the characters perform expressive function intends to vent some feelings and evoke the same feeling from other people based on the context of the conversation. So, the emotion was not meaningful without context.

The emotive function is also called the expressive function. The emotive function is a function of the language used to express human feelings. For example, feeling satisfied with something, sad, happy, angry, and so on. Based on Jacobson (1960) in Cook
(1989, p. 27), there are seventeen kinds of emotive functions. They are pleasure, displeasure, like, dislike, surprise, hope, satisfaction, dissatisfaction, disappointment, worry, preference, gratitude, sympathy, intention, want, dear and desire. Expressions that occur when speakers interact with other people can provide understanding to the listeners. For example, when someone is angry with something, he or she will show his or her attitude in a way of silence, even being asked he or she will not answer. This makes the listeners understand the expression and gives the impression that the speakers are angry.

This research can help the audience to understand well the use of the emotive functions by actors in the talk show. The researcher wants to analyze a talk show instead of a film or novel because in a novel or film the emotions are shown by the characters are arranged by the author of the novel, while in a talk show, emotions expressed by the presenter or guest star. It appeared is spontaneous without any engineering. It concerns daily life that people's emotions arise spontaneously without being planned.

Moreover, the talk show that analyzed is the Ellen DeGeneres talk show. Ellen DeGeneres talk show is a talk show that funny so that the audience 
feels entertained when watching this talk show. However, it never be known whether the comedies presented by Ellen are indeed funny or there is a message which is not known by the audience. So, the researcher is interested to analyze the Ellen DeGeneres show as an object of research. The researcher formulated research question to get the main purpose of this study is how do the emotive language functions work in performance by the actors "Ellen with Will Smith Full Interview" talk show.

Based on the explanation above, the researcher analyzed the emotive language functions in the Ellen DeGeneres talk show's transcript used (Jacobson, 1960). There are seventeen kinds of emotive functions; pleasure, displeasure, like, dislike, surprise, hope, satisfaction, dissatisfaction, disappointment, worry, preference, gratitude, sympathy, intention, want, dear and desire (Jacobson 1960) in Cook (1989, p. 27).

\section{METHODOLOGY}

\subsection{Discourse analysis}

The discourse analysis is committed to an investigation of what that language is used for. While the formal approach as a long tradition manifested in innumerable volumes of grammar, the functional approach is less well document (Brown and Yule 1983, p.1). According to Jackson and Stockwell 2011 in Sean Sutherland, discourse analysis can be done to either spoken language or written language. Some author makes a distinction between "spoken text and written text". Written text is text in the form of writing such as newspapers, letters and so on. While spoken text is text in the form of tape recordings that is transcribed into writing.

According (Jinadu, 2006) in UK Essay, that there are three main points in discourse analysis:

1. Discourse analysis deals with the nations of the sentence in grammar as the basic level from which grammatical or semantic meaning derive.

2. In Discourse analysis, message and shared experience became interactive.

3. There is the concept of context, and in discourse analysis is the meanings of discourses.

\subsection{Context}

Context is a collection of text, which describes the situations in writing. The context is the domain of reference of a given text, the co-text, 
the genre of speech event in progress, the discourse constructed upstream, the socio-cultural environment assumed by the text, and the specific utterance situation at hand, subject to a continuous process of construction and revision as the discourse unfolds.

Based on (Jinadu, 2006) in UK Essay, there are four types of relevant contexts are often identified by discourse analysis. They are the situational context, social context, cognitive context, and cultural context.

1. Situational context is one of the recognized contexts which take into account the physical environment of the discourse.

2. Social context is the context that operates among interlocutors which concerns the interpersonal and interactional relationship.

3. The cognitive context is the context which deals with the message that goes on from the speaker to the hearer functions between their shared experiences.

4. Cultural context involves the worldview of both the speaker and the hearer which may be interpreted in terms of cultural beliefs and practices of the people.

In conducting communications, context relates to the element of communications. (Hymes, 1974) mentioned the acronym of SPEAKING.

1. S: Setting and scene, it includes both the scene and setting. This is where the activities are taking place and the overall scene in which day is a part.

2. P: Participants, it includes the people present and the roles they play, or the relationships they have with other participants.

3. E: Ends, the purpose and the goals of communication can be studied.

4. A: Acts, it includes both form and content. It is any actions can be considered a communicative action if it conveys meaning to the participants.

5. K: Key is a tone of speech. It is the speech sounds or was delivered.

6. I: Instrumentality is the channel through which communication flows can be examined. 
7. N: Norms are the rules guiding talk and its interpretation can reveal meaning.

8. G: Genres are textual categories of speech, such as proverbs, apologies, prayers, small talk, and so on

\subsection{Emotive Functions}

Talk about emotive functions, it means that talk about people's feelings, their condition, and how they deliver their feeling. The emotive function shows the speaker's attitudes when they speak to their audience (Jacobson 1960, p. 354). Based on Leech in Ba'dulu (2009, p. 5), the expressive function is expressing the speakers' or writers' feelings or attitudes. The emotive term put forward by Marty is better known as an emotional term. The emotive function is delivered with an exclamation word. Emotive differs from referential either by its sound patterns, strange sound sequences or even unusual sounds and syntactic roles (Jacobson 1960, p. 354).

Based on Beijer (2003, p. 9) states that the term emotional/expressive utterance refers to any utterance in which the speakers in question are emotional involved, and in which this involvement is linguistically expressed using intonation or by the use of performance expressions.

Based on Jacobson's (1960) in Cook $(1989$, p. 27), there are seventeen kinds of emotive functions that used by speakers to describe their emotions as follows:

1. Pleasure is a good activity and gives a sensation of pleasure or emotion. This expression has the function to express the speaker's feelings for pleasure or satisfaction. For example, "today is a good day"

2. Like, the feelings of people likes something and used in a good condition, especially when people are happy and other situations that give rise to someone's impression. For example "Extraordinary!", "amazing".

3. Displeasure, the feelings of people who feel unhappy, upset or dissatisfied with someone or something. This serves to determine what the speakers intend to vent their feelings. For example: "Huh,Ugh, Nonsense".

4. Dislike is the feeling of someone who doesn't like something and sometimes makes the speakers are angry. Example "oh no, he makes me sick"

5. Surprise, someone's feelings when feeling something extraordinary. 
Example: "oh wow! That is unbelievable!",

6. Hope, people's feeling who hopes something good will happen to them. This expression is used to express the state of people according to their wishes. For Example: "God, I wish I can do it".

7. Satisfaction, the feeling of someone who is satisfied with something he gets. This happens in certain situations when the speakers has done something difficult or complicated and how someone feels is sometimes more important than what he/she thinks is right. For Example: "that's wonderful!" and "fantastic!".

8. Dissatisfaction, the circumstances of people who are dissatisfied with something they get or something that is not right for them. Example: "this is hopeless".

9. Worry, the expression of someone who is used in a complicated situation and shows anxious attitude towards something or someone. Example: "take care", "be careful on your way"

10. Preference, a choice made by someone. Often used by someone to choose something good to do. Example: "I'd rather go shopping this afternoon".
11. Gratitude, thankfulness when someone gets something good. Example: "thanks to God".

12. Sympathy is a feeling or attitude of someone who is attracted to others due to certain factors. This expression is usually expressed by congratulating someone who has achieved an achievement. Example: "What a pity!"

13. Intention, expected outcomes that are intended or that guide the actions you plan. Example: "just calm down!"

14. Want, desire or hope for something. This expression has the characteristics of when people need something or have ambitions to realize these ambitions. Example: "fighting!"

15. Desire is strong to wish to have or doing something. For instance, "never give up!"

16. Dear, used in the salutation of a letter as an expression of affection or respect or as a conventional greeting. It is actually as a kind of common expression when people want to send something to others. For Example: "Dear, sir".

17. Disappointment is the expression of someone for something that is not in accordance with their expectations. This expression 
usually occurs when people receive and get something that is not appropriate for them. For example:

In this research used the qualitative method to describe the emotive language functions. Ospina (2004) mention that the goal of qualitative studies is a comprehension summarization, in everyday terms, of specific events experienced by individuals or groups of individual. This research aims to describe emotive functions in the Ellen DeGeneres Talk Show's transcript. The study used conversation in The Ellen DeGeneres Talk Show's transcript from YouTube. The researcher took video of this Talk Show "Ellen with Will Smith full interview" (18.23 minutes).

\section{RESULT}

The researcher presents the data based on conversation between Ellen and the guest star in the Ellen DeGeneres talk show on NBC-TV. The researcher found there are five kinds of emotive language functions from three videos of Ellen DeGeneres talk show. The videos Ellen with Will Smith full interview with the guests star Will Smith, Mena Massoude and Naomi Scott found there are five kinds of emotive functions. They are pleasure, like, dislike, surprise, and gratitude.

In the result, the researcher found there are five kinds of emotive functions of Video "Ellen with Will Smith full interview" (18.23 minutes). In this video, Will Smith explains how he persuaded his wife to go skydiving for his $50^{\text {th }}$ birthday and his experience bungee jumping out of a helicopter over the Grand Crayon. Then, Ellen welcomed the "Aladdin" star also chatted with co-stars Mena Massoud and Naomi Scott about bringing beloved Disney characters to life and played a game with the audience called "Rub My Lamp", giving some lucky fans huge prize. In this video, the researcher found the data as follows:

a. Pleasure

\section{In the datum 1}

\section{Smith: It's been great.}

Ellen: All right, thank you.

Smith: That's all we've got time for. All right, that's all.

Ellen: Yeah.

This utterance is an expression of pleasure. This utterance is expressed by Will Smith because he has been invited to the Ellen DeGeneres talk show. Smith issued the sentence to describe his feeling of pleasure to Ellen who has invited him to the event. 
b. Like

In the datum 2

Ellen: It was wonderful. It's so-- I always love when I know you're going to be on the show. You're so much fun.

And this couldn't be a better time for me because I don't feel well, and you just made--

Smith: Oh no, I got it. I got it.

Ellen: Just relax.

This utterance is an expression of like. This utterance is expressed by Ellen when Smith tells her to stand by his side and made the Smith look so cool.

In the datum 3

Smith: And so we went up there. And then, there's this dark internet where you can find all kinds of stuff like that. So you know, I've been hanging with too many 20 year-olds. So we found that. We went up. We went on there. We shot it. My buddy had a drone. And we did the whole thing.

Ellen: Amazing. You do all these things. I have this here, and it's going to be fine. But I have this...

Smith: Oh, oh, oh!
This utterance is one of the expressions of like. This expression is used by someone when he/she like a thing or an event. The word "Amazing" is the utterance that expressed by Ellen when Ellen heard Smith's story that Smith can do everything like being able to play movies, rap and so on. Ellen is amazed at the talent that Smith has.

In the datum 4

Ellen: And you sing. We know you as a rapper. But then you sing in this.

Smith: Yes, I sing!

Ellen: It's great.

This utterance is an expression of like. This utterance is expressed by Ellen when Smith tell her that he sing the Aladdin's song with a pop genre while Smith himself is a rap singer. Ellen is amazed and really likes the talent that Smith has.

c. Dislike

In the datum 5

Smith: Have you ever jumped? Have you ever?

Ellen: No. You know when I was younger; I thought that I wanted to do that. It was kind of a dream of mine. And as I got older and wiser, I decided. I don't want to do that 
It is categorize the expression of dislike. Expressions of dislike are usually expressed by someone when she/he gets something which they don't like.

I don't want to that, is the utterance revealed by Ellen when offered by Smith to do a jump together. Ellen didn't like that because she is traumatized since she was young about jumping.

In the datum 6

Smith: We should do it together.

Ellen: No, no.

Smith: We would break the internet if we did it together.

This utterance is categorized of dislike. This utterance is expressed by Ellen when Smith convinced Ellen to jump together. Ellen really does not like the invitation made by Smith.

d. Surprise

In the datum 7 ,

Smith: Wow, well, thanks a lot, Ellen! Oh, yeah. It's been great.

Ellen: All right, thank you.

Smith: That's all we've got time for. All right, that's all.

Ellen: Yeah.

It is categorizing the expression of surprise. Seeing in the context, this utterance is expressed by Will Smith who is very impressed in the Ellen DeGeneres talk show. This expression always uses by someone when he/she gets something.

e. Gratitude

In the datum 8

Mena Massoud: Yeah, very blessed. Yes. We're very blessed to be here and grateful. And we hope people like the film.

Ellen: I think they will.

This utterance is a kind of expression of gratitude. This utterance is expressed by Mena Massoud because she was very grateful to Ellen for being invited as the guest star of the Ellen DeGeneres Talk show.

In this part, the researcher presents the data that have been found based on the talk show's transcript. In addition, the researcher explains each expression by looking at the context based on the Jacobson theory in the emotive language functions. The researcher examined Ellen with Will Smith full interview with the guest star Will Smith, they discuss the birthday of Will Smith's wife and his experience as a Jinni actor in the film Aladdin. Besides that, the researcher explains each expression by looking at 
the context based on the Jacobson theory in emotive language functions.

In the data above, the researcher found pleasure, like, dislike, surprise, and gratitude. So, in the Ellen DeGeneres talk show, the emotive functions that are often used by Ellen and the guest stars are the five kinds of emotive functions namely pleasure, like, dislike, surprise and gratitude. The most emotive function that frequently used in the Ellen DeGeneres Talk Show is "like expression" because this talk show is entertaining and the topics discussed are according to what the guest stars like. Based on Jacobson's theory, Like expression is the feelings of people likes something and used in a good condition, especially when people are happy and other situations that give rise to someone's impression.

In additions, this study deals with Wahyuni(2014)'s previous research but from previous study Wahyuni took Novel as object to identified while in this research used talk show as object of the research. Wahyuni also focuses on finding emotive functions that uses in the novel heart of the matter. She analyzed kinds of the emotive language functions in the main characters in the novel heart of the matter. Wahyuni's previous research (2014) finds that the emotive language functions performed by the character in the novel were various, and she found seven kinds there are surprise, disappointment, displeasure, worry, pleasure, sympathy, and gratitude. While in this research, the researcher also found the emotive functions work in performance by the actors in the Ellen DeGeneres Talk Show were various and the researcher found five kinds of emotive language functions there pleasure, like, dislike, surprise and gratitude. While in the talk show, the emotive language functions that found there are five kinds, and in the novel there are seven kinds, because in the talk show the emotive language functions that are often used by people in formal form. Meanwhile in the novel, the people used the emotive language functions based on the context of the conversation.

\section{CONCLUSION}

There are five types of emotive language functions used by the guest star in the Ellen DeGeneres talk show in five expressions are often used by Ellen and the guest stars because in the talk show, Ellen and the guest stars express their feelings in accordance with the conditions that occur with them. They also express their feelings in a polite manner even though there is something 
they don't like because they are public figures known by the public, so they must be careful in expressing their feelings. The most emotive function that frequently used in the Ellen DeGeneres Talk Show is "like expression" because this talk show is entertaining and the topics discussed are according to what the guest stars like. The emotive functions work in performance by the actors in the Ellen DeGeneres talk show to express the actor's feelings to other people based on the context and situation of the conversation.

\section{REFERENCES}

Agustina, Leonia and Chaer, Abdul (2004). Sosiolinguistik. Rineka cipta.

Armstrong, Elizabeth. (2010). Language, Meaning, Context, and Functional Communication. Cowan University.

Ba'dulu, Abdul Muis.( 2009). Introduction to Linguistics. Makassar : Badan Penerbit Universitas Negeri Makassar.

Beijer, Fabian (2003). Insights Into the Syntax and Pragmatics of Exclamation and Other Expressive/Emotional Utterance.

Brown, Gillian and Yule, George (1983). Discourse Analysis. Australia: Cambridge University Press.
Cook, Guy (1989). Discourse: Language Teaching; A Schema for Teacher Education. Oxford New York Toronto, Oxford University Press.

Essay, UK. (November 2013). Context is Fundamental to Discourse Analysis English Language Essay.https:www.ukessay.com/ess ay/english-language/context-isfundamental-to-discourse-analysisenglish-language-essay.

George, Yule. (1996). Pragmatics. New York. Oxford University Press.

Hymes, Dell. (1974). Foundations of Sociolinguistics: An Ethnographic Approach. Philadelphia.

Jacobson, Roman (1960). Closing Statement:Linguistics and Poetics. In Sebeok (ED). Cambridge Mass: MIT press.

Ospina, Sonia. (2004). Qualitative Research. New York University. (journal article www.sagepublications.com)

Sutherland, Sean.(2016). A Beginner's Guide to Discourse Analysis. University of Westminster, UK: Palgrave.

Wahyuni, Arma. (2014). Emotive Function In Emily Giffin's Novel "Heart Of The Matter". Alauddin State Islamic University of Makassar. 